\title{
Role of a natural disturbance in an assemblage of marine free-living nematodes
}

\author{
Kevin M. Sherman ${ }^{1}$, Jeffrey A. Reidenauer ${ }^{1}$, David Thistle ${ }^{1}$ and Duane Meeter ${ }^{2}$ \\ ${ }^{1}$ Department of Oceanography, Florida State University, Tallahassee, Florida 32306, USA \\ ${ }^{2}$ Department of Statistics, Florida State University, Tallahassee, Florida 32306, USA
}

\begin{abstract}
One of the predictions of theoretical treatments of soft-bottom benthos is: if disturbance were responsible for the persistence of a species in a community, that species should become disproportionately abundant in recently disturbed patches. We investigated this prediction using marine free-living nematode species in subtidal (2 to $3 \mathrm{~m}$ depth) sediments off the Florida panhandle $\left(29^{\circ} 54.55^{\prime} \mathrm{N}, 84^{\circ} 31.45^{\prime} \mathrm{W}\right)$, frequently disturbed by stingrays (Dasyatis sabina). In disturbed sediments nematode densities gradually increased over $4 \mathrm{~d}$ until they exceeded abundances in background sediments $96 \mathrm{~h}$ after the initial disturbance. None of the species examined responded to disturbance in the manner expected. We conclude that small-scale natural disturbances are not important in the maintenance of nematode species in this community.
\end{abstract}

\section{INTRODUCTION}

The role of disturbances (disasters sensu Harper, 1977) in the organization of ecological communities has occupied the thoughts of ecologists for almost a century (e. g. Clements, 1916). Several contemporary ecologists have concluded that natural disturbances play an important role in structuring a variety of communities (Platt, 1975: terrestrial plants; Cairns et al., 1976: freshwater protozoans), in particular communities of sessile marine organisms on hard bottoms (Dayton, 1971, 1973; Osman, 1977; Connell, 1978; Paine, 1979; Sousa, 1979).

The importance of disturbance in the organization of soft-bottom communities is less established. Grassle and Sanders (1973; see also Johnson, 1970) have presented a model in which disturbances create a mosaic of patches of different ages. Species that are inferior resource competitors persist in the community by locating and exploiting the early portion of the recovery of disturbed patches, where their competitors are reduced or absent. One would expect that species that are maintained in the community by disturbance will become disproportionately abundant early in the recolonization of a patch. This prediction has been tested in soft-bottom communities but with inconsistent results (VanBlaricom, 1978, 1982; Thistle, 1980; Reidenauer and Thistle, 1981).
In this study of soft-bottom disturbance, we investigated the response of marine free-living nematode species to a natural disturbance in the form of feeding pits created by the Atlantic stingray Dasyatis sabina (LeSeur) as it searched for macro-infaunal prey. The goals of the study were to (1) see if nematode abundances were reduced in ray pits; (2) discover how long such reduced abundances persist; and (3) examine the recovering assemblage at the species level to determine whether any nematode species became disproportionately abundant in disturbed patches thereby testing the prediction of the Grassle and Sanders (1973) model.

\section{MATERIALS AND METHODS}

We selected a study area at $2 \mathrm{~m}$ depth in St. George Sound $300 \mathrm{~m}$ off the coast of the Florida panhandle $\left(29^{\circ} 54.55^{\circ} \mathrm{N}, 84^{\circ} 31.45^{\prime} \mathrm{W}\right)$ The site is adjacent to a seagrass meadow, and the bottom is a fine sand $(2.2 \varnothing$ graphic mean) with a 2 to $3 \mathrm{~mm}$ flocculent layer. During a 24-h period, current velocities measured at $20 \mathrm{~cm}$ above bottom averaged $4.3 \mathrm{~cm} \mathrm{~s}^{-1}$. There is little wave action in the absence of storms. Oxidized sediments extend to 1 to $3 \mathrm{~cm}$ depth. Ray pits are dug in this area between March and November.

A $60-\mathrm{m}^{2}$ area that experienced frequent disturbance 
by rays was permanently marked with 3 parallel, $10-\mathrm{m}$ transect lines placed $3 \mathrm{~m}$ from one another. The lines were tagged at $10-\mathrm{cm}$ intervals. A $3-\mathrm{m}$ cross line, also tagged at $10-\mathrm{cm}$ intervals, was used by SCUBA divers to form a set of Cartesian coordinates that allowed accurate mapping of ray pit positions.

The area was mapped $7,6,5,3,1$, and $0 \mathrm{~d}$ prior to sampling. Fresh feeding pits were recognizable for $3 \mathrm{~d}$ before they became indistinguishable from the background topography. These daily mappings were used to (1) calculate the percent of the study site disturbed by the rays; (2) locate areas undisturbed for at least 10 d in which to take background samples; (3) identify pits made the night before the first sampling time.

The study involved sampling a pit over time so that accurate relocation was required. Accordingly, a removable $3-\mathrm{m}$ steel rod was positioned horizontally above a pit. The pit center was marked on the rod, and PVC stakes were placed at each end. Pits were relocated by positioning the rod on the appropriate stakes and finding the correct center mark. Relocation was accurate to $1 \mathrm{~cm}$. A background site was selected $50 \mathrm{~cm}$ away from each pit and at the same distance from the transect line as the pit and located using the same technique. (Rays dig pits in such a way that the excavated sediment is expelled in one direction. Control sites were chosen to avoid this side of the pit and were placed on sites that were visually indistinguishable from the sediment surface further from the pit.) A plexiglass template was placed over the positioning rod to divide the pit and background sites into 4 quadrants that were randomly chosen to be sampled, one at each of the 4 sampling times (Hours 0, 24, 48, 69). Two of 6 possible core positions within each quadrant (also chosen randomly) were sampled with $3.5-\mathrm{cm}$ diameter cores. This procedure was used to sample each of 3 replicate natural pits and their paired controls.
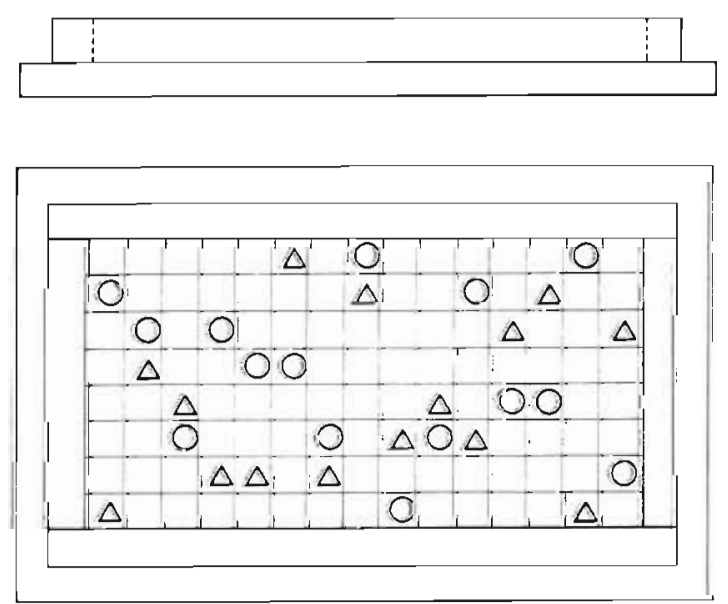

Fig. 1. Lateral and vertical schematic views of the sampling tray with a hypothetical symbol arrangement
The ray pits were made sometime during the night before Hour 0 , but their precise ages could not be determined. To investigate the early stages of recolonization, and to determine a more accurate age of the natural pits, SCUBA divers created replicate artificial pits by digging holes with a bucket to equal the dimensions of natural pits. The 2 artificial pits were sampled over a shorter time scale (Hours 0, 5, 24, 29 - short-term pits) using the techniques described above.

For all cores the overlying water and top 1-cm layer were preserved with $4 \%$ formaldehyde. Ten $14-\mathrm{cm}$ cores were taken in background areas and sliced into $1-\mathrm{cm}$ layers. In these cores, $62 \%$ of the nematodes were in the top 1-cm layer. All of the numerically dominant nematode species had their abundance maximum in the $0-1 \mathrm{~cm}$ layer.

Nematodes were separated from sediment using the Barnett sorting trough (Barnett, 1968; mean efficiency $99 \%, N=15$ ), retained on a $50 \mu \mathrm{m}$ sieve, and stained with rose bengal before sorting under a dissecting microscope. The harpacticoid copepods from these samples have been reported on elsewhere (Reidenauer and Thistle, 1981). Because nematodes were 10 times more abundant than harpacticoids, a technique was devised that allowed all of the harpacticoids to be sampled and only a fraction (we chose 1/4) of the nematodes to be collected without bias. Our procedure used a clear plexiglass sorting tray with well dimensions $9.5 \mathrm{~cm}$ by $5 \mathrm{~cm}$ by $1 \mathrm{~cm}$ (Fig. 1). The grid on the bottom of the tray divided the interior into 120 cells ( 8 rows by 15 columns). We attached a paper sheet to the underside of the tray with 2 different symbols arranged to fall beneath 30 of the cells. We used a stratified random arrangement of symbols; one of each symbol type was placed in cells of each of the 15 columns. Cells without such symbols were not sorted for nematodes. Nematodes that fell completely within the boundaries of cells with 1 symbol type were picked. Nematodes that fell completely or partially within a cell of the second symbol type were also picked. (In using this method, the operator did not need to decide whether a nematode was half in or half out of a cell.) The sample was spread as evenly as possible in a sorting tray that contained a $0.4 \%$ solution of tap water and Calgon ${ }^{\circledast}$ (added to prevent the nematodes from floating) and scanned under the dissecting microscope.

The statistical model used to test for differences in total nematode abundance between pit and background samples at each time was a treatment by block, two-way ANOVA, with the treatment factor (disturbed versus background) fixed, and the blocking factor (between-pit differences) random (mixed model; Sokal and Rohlf, 1969). Each species was tested for disproportionate abundance using the Mantel-Haenszel test as described in Snedecor and Cochran (1976). For each 
pair of pit and background samples, one can construct a $2 \times 2$ contingency table and calculate the probability that a species occurs in the same proportion in background and pit samples. The Mantel-Haenszel test allows these contingency tables to be combined into a single test (in this case 3 pairs of pit and background samples). The $5 \%$ significance level was used in all statistical comparisons.

\section{RESULTS}

The efficiency of the subsampling procedure is demonstrated in Table 1 . The table shows that the procedure permits one to pick $1 / 4$ of the nematodes $\pm 1 \%$. We used linear regression to test for depend-

Table 1. Efficiency data for subsampling procedure. The expected percent in the sample was $25 \%$

\begin{tabular}{|ccc|}
\hline $\begin{array}{c}\text { Total } \\
\text { nematodes }\end{array}$ & $\begin{array}{c}\text { Number } \\
\text { in subsample }\end{array}$ & $\begin{array}{c}\text { Percent } \\
\text { in subsample }\end{array}$ \\
\hline 1002 & 251 & 25.05 \\
649 & 161 & 24.81 \\
959 & 244 & 25.44 \\
388 & 94 & 24.23 \\
957 & 244 & 25.50 \\
811 & 209 & 25.77 \\
904 & 218 & 24.12 \\
505 & 124 & 24.55 \\
390 & 94 & 24.10 \\
\hline
\end{tabular}

ence of subsampling efficiency $(y)$ on abundance $(x)$. The regression equation $(\mathrm{Y}=-1.35+.0016 \mathrm{X})$ was used to test the null hypothesis $\beta$ (slope) $=0$ versus the 2 -sided alternative $\beta \neq 0$. An ANOVA for simple linear regression was unable to reject this hypothesis $(F=4.96, p>0.05) ;$ therefore, subsampling efficiency appears to be independent of nematode density. However, when the number of nematodes in the subsample was less than 50, the error increased greatly (range $23.39 \%$ to $27.60 \%$ ). Consequently, we completely sorted nematodes when the number of nematodes in the subsample was less than 50 ( 200 total nematodes).

To investigate the performance of the sorting technique at the species level, we identified the 20 most abundant nematode species in the subsample and in the remainder from 4 samples. We used these data in a 2 -celled $\chi^{2}$ test that the binomial probability of any species being included in the subsample was $1 \%$ (Table 2 ). No species departed from expectation. We concluded that (1) the technique gave an unbiased and precise subsample of the total number of nematodes in a sample; (2) sampling was independent of speciesspecific properties.

Ray disturbance was a prominent feature of the study site during the experiment (see Reidenauer and Thistle, 1981, Table 1). The average dimensions of the pits, as well as the total area covered by pits, varied little over the course of the experiment. From the 3 available estimates of percent of area disturbed by new pits per day, a $75 \%$ distribution-free confidence interval (Conover, 1971 ) is $0.71 \%$ to $1.04 \%$. Assuming that

Table 2. Rank order abundance and percent composition for the 20 most dominant nematode species and a 2-celled $\chi^{2}$ test of subsampling accuracy averaged over 4 samples $\left(\chi^{2} .05,4 \mathrm{df}=9.488\right)$

\begin{tabular}{llccc|}
\hline & & & \multicolumn{2}{c|}{$\begin{array}{c}\text { Cumulative } \\
\%\end{array}$} \\
Species & Rank & \% of Total & $\Sigma_{1}^{4} \chi^{2}$ \\
\hline Theristus sp. a & 1 & 16.6 & 16.6 & 1.00 \\
Chromaspirina sp. a & 2 & 9.4 & 26.0 & 5.82 \\
Metachromadora (Metachromadoroides) sp. a & 3 & 7.7 & 33.7 & 1.26 \\
Viscosia brachylaimoides & 4 & 6.3 & 40.0 & 2.93 \\
Monoposthia sp. & 5 & 5.7 & 45.7 & 6.20 \\
Theristus sp. b & 6 & 5.0 & 50.7 & 2.01 \\
Chromadorella sp. & 7 & 4.6 & 55.3 & 0.55 \\
Metachromadora (M.) sp. b & 8 & 4.1 & 59.4 & 0.30 \\
Innocuonema sp. a & 9 & 3.2 & 62.6 & 2.18 \\
Microlaimus sp. & 10 & 2.8 & 65.4 & 1.18 \\
Innocuonema sp. b & 11 & 2.4 & 67.8 & 2.11 \\
Desmodora sp. & 12 & 2.2 & 70.0 & 0.40 \\
Sabatieria sp. & 13 & 2.0 & 72.0 & 1.04 \\
Metachromadora (M.) sp. c & 14 & 2.0 & 74.0 & 1.87 \\
Chromaspirina sp. b & 15 & 1.8 & 75.8 & 2.81 \\
Theristus sp. c & 16 & 1.8 & 77.6 & 0.65 \\
Innocuonema sp. c & 17 & 1.5 & 79.1 & 0.89 \\
Oncholaimus sp. & 18 & 1.4 & 80.5 & 0.96 \\
Tricordorina sp. & 19 & 1.3 & 81.8 & 3.33 \\
Metachromadora (M.) sp. d & 20 & 1.3 & 83.1 & 2.20 \\
\hline
\end{tabular}




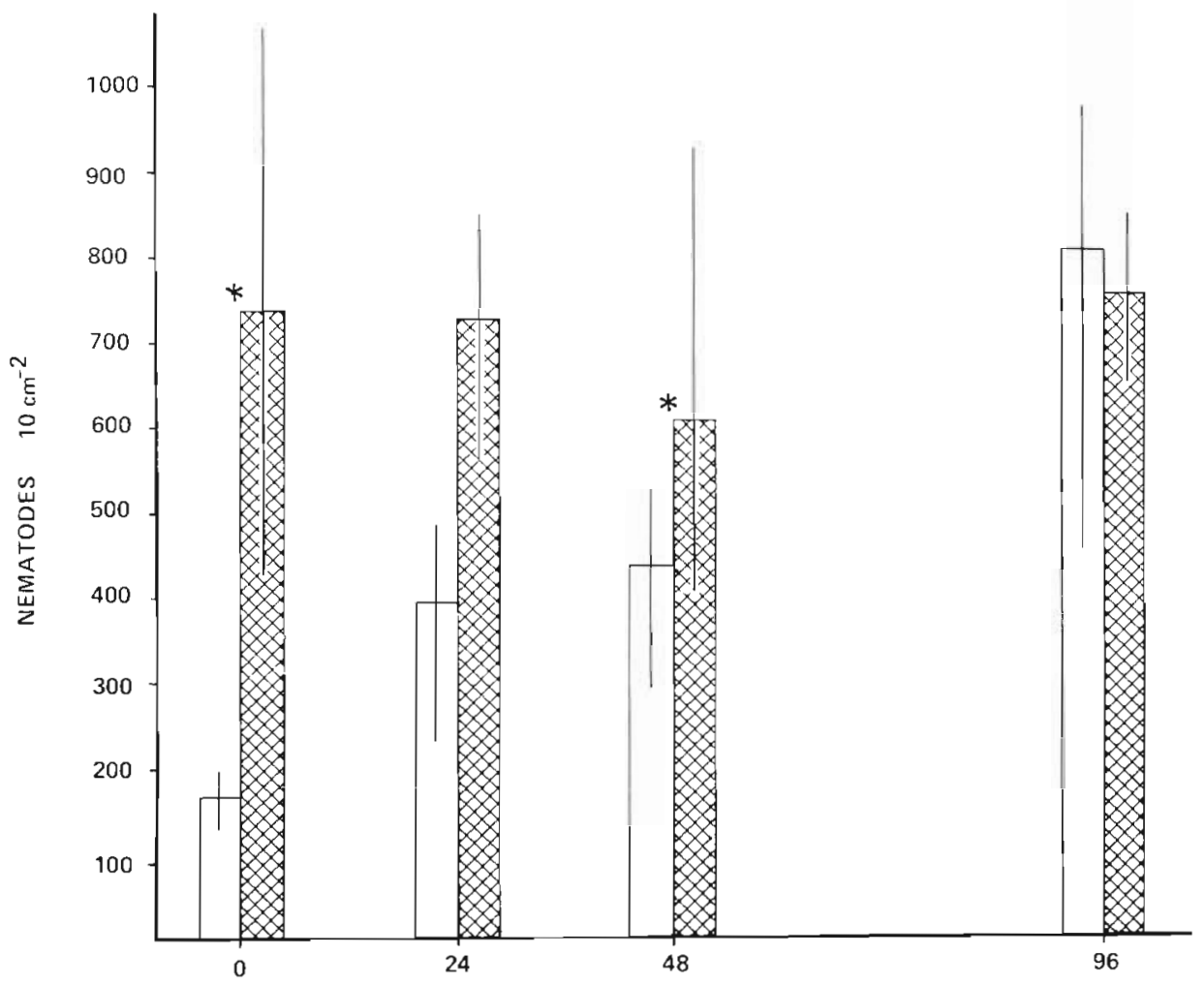

TIME SINCE INITIATION, h
Fig. 2. Mean nematode abundances in the 3 natural pits (clear) and the background samples (hatched), at the 4 recovery times. Bars: overall mean; error lines: range. Significant differences between means marked with an asterisk (")

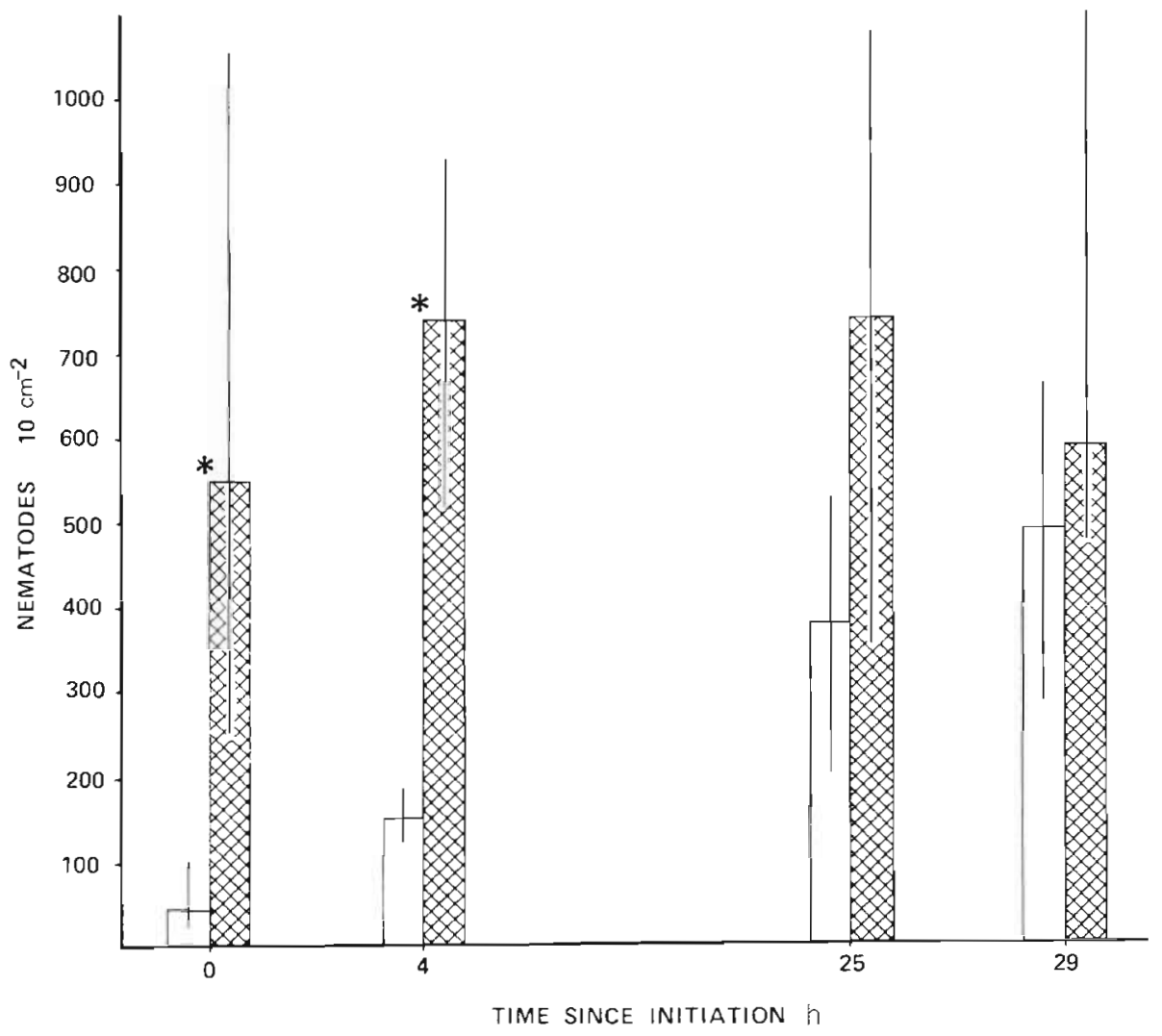

Fig. 3. Mean nematode abundances in the 2 artifical pits (clear) and the background samples (hatched) at the 4 recovery times. Bars: overall mean; error lines: range. Significant differences between means marked with an asterisk (") 
new pits never overlap old ones and using the higher estimate yields $50 / 1.04=48 \mathrm{~d}$ to disturb $50 \%$ of the area. Alternatively, assuming that new pits are placed randomly with respect to old ones and using the lower estimate, we find that $(1-0.0071)^{\mathrm{n}}=0.5$ is solved by $\mathrm{n}=97 \mathrm{~d}$ to disturb $50 \%$ of the area. In either case, ray disturbance could be expected to have significant impact on the study site.

Table 3. Abundances (numbers $9.6 \mathrm{~cm}^{-2}$ ) of dominant nematode species in the first half of the data 1 from pit (P) and background samples (B) at 4 recovery times. For consistency of presentation, nematode abundances obtained using the subsampler were multiplied by 4

\begin{tabular}{|c|c|c|c|c|c|c|c|c|c|c|c|c|}
\hline \multirow[b]{2}{*}{ Species } & \multicolumn{6}{|c|}{ Hour 0} & \multicolumn{6}{|c|}{ Hour 24} \\
\hline & $\mathrm{p}^{\circ}$ & $1 \mathrm{~B}$ & $\mathrm{p} \cdot$ & 2 B & $\mathrm{P}^{\cdot}$ & $3 \mathrm{~B}$ & $\mathrm{P}$ & $1 \mathrm{~B}$ & $\mathrm{P}$ & ${ }^{2} \mathrm{~B}$ & $\mathrm{P}$ & ${ }^{3} \mathrm{~B}$ \\
\hline Theristus sp. a & 19 & 224 & 4 & 20 & 46 & 192 & 104 & 116 & 52 & 40 & 60 & 108 \\
\hline Chromaspirina sp. a & 8 & 100 & 38 & 64 & 6 & 32 & 12 & 76 & 24 & 80 & 8 & 48 \\
\hline Metachromadora (Metachromadoroides) sp. a & 18 & 68 & 38 & 56 & 12 & 24 & 60 & 40 & 68 & 44 & 24 & 60 \\
\hline Viscosia brachylaimoides & 8 & 92 & 12 & 32 & 11 & 24 & 28 & 16 & 20 & 20 & 16 & 44 \\
\hline Monoposthia sp. & 12 & 56 & 15 & 52 & 4 & 24 & 44 & 40 & 0 & 40 & 28 & 24 \\
\hline Theristus sp. b & 14 & 12 & 14 & 12 & 8 & 8 & 12 & 4 & 12 & 24 & 16 & 28 \\
\hline Chromadorella sp. & 7 & 92 & 7 & 12 & 0 & 88 & 4 & 28 & 20 & 8 & 24 & 60 \\
\hline Metachromadora (M.) sp. b & 5 & 56 & 10 & 48 & 0 & 20 & 28 & 16 & 8 & 32 & 4 & $\varepsilon$ \\
\hline Innocuonema sp. a & 9 & 20 & 6 & 8 & 1 & 12 & 8 & 24 & 16 & 16 & 4 & 16 \\
\hline Microlaimus sp. & 2 & 20 & 8 & 12 & 10 & 8 & 12 & 44 & 8 & 28 & 8 & 24 \\
\hline Innocuonema sp. b & 12 & 16 & 5 & 4 & 20 & 24 & 16 & 4 & 20 & 20 & 4 & 12 \\
\hline Desmodora sp. & 8 & 28 & 10 & 16 & 2 & 4 & 12 & 24 & 44 & 28 & 12 & 12 \\
\hline Sabatieria sp. & 1 & 40 & 2 & 0 & 0 & 12 & 8 & 40 & 16 & 4 & 0 & $\varepsilon$ \\
\hline Metachromadora (M.) sp. c & 0 & 0 & 3 & 16 & 1 & 8 & 0 & 0 & 0 & 4 & 0 & c \\
\hline Chromaspirina sp. b & 3 & 28 & 3 & 12 & 0 & 0 & 4 & 40 & 8 & 4 & 8 & 28 \\
\hline Theristus sp. c & 4 & 28 & 0 & 0 & 1 & 4 & 16 & 36 & 0 & 12 & 12 & 16 \\
\hline Innocuonema sp. c & 1 & 0 & 1 & 4 & 11 & 8 & 0 & 0 & 0 & 8 & 0 & 8 \\
\hline Oncholaimus sp. & 1 & 4 & 4 & 4 & 3 & 0 & 0 & 16 & 8 & 8 & 0 & 4 \\
\hline Tricordorina sp. & 10 & 16 & 0 & 0 & 0 & 0 & 8 & 16 & 8 & 12 & 0 & 12 \\
\hline Metachromadora (M.) sp. d & 0 & 0 & 5 & 0 & 18 & 8 & 0 & 0 & 16 & 36 & 0 & 4 \\
\hline \multirow[t]{3}{*}{ Total (all species) } & 159 & 1184 & 196 & 428 & 192 & 576 & 480 & 764 & 432 & 560 & 236 & 668 \\
\hline & \multicolumn{6}{|c|}{ Hour 48} & \multicolumn{6}{|c|}{ Hour 96} \\
\hline & $\mathrm{p}$ & $1 \mathrm{~B}$ & $\mathrm{P}$ & 2 B & $P$ & ${ }^{3} \mathrm{~B}$ & $\mathrm{P}$ & $1 \mathrm{~B}$ & $\mathrm{P}$ & ${ }^{2}$ B & $\mathrm{P}$ & $3 \mathrm{~B}$ \\
\hline Theristus sp. a & 80 & 172 & 56 & 120 & 32 & 60 & 120 & 228 & 176 & 192 & 224 & 60 \\
\hline Chromaspirina sp. a & 48 & 132 & 52 & 88 & 28 & 144 & 28 & 48 & 64 & 40 & 84 & 84 \\
\hline Metachromadora (Metachromadoroides) sp. a & 76 & 56 & 44 & 36 & 92 & 60 & 16 & 20 & 32 & 56 & 64 & 60 \\
\hline Viscosia brachylaimoides & 28 & 56 & 36 & 76 & 4 & 24 & 44 & 64 & 44 & 76 & 52 & 36 \\
\hline Monoposthia sp. & 48 & 36 & 64 & 36 & 12 & 32 & 32 & 36 & 60 & 60 & 60 & 72 \\
\hline Theristus sp. b & 24 & 24 & 60 & 16 & 28 & 8 & 16 & 8 & 28 & 40 & 8 & 40 \\
\hline Chromadorella sp. & 4 & 64 & 8 & 12 & 0 & 16 & 8 & 20 & 116 & 28 & 32 & 28 \\
\hline Metachromadora (M.) sp. b & 36 & 44 & 24 & 36 & 36 & 16 & 16 & 32 & 44 & 40 & 80 & 52 \\
\hline Innocuonema sp. a & 24 & 32 & 48 & 12 & 36 & 0 & 12 & 0 & 4 & 36 & 0 & 8 \\
\hline Microlaimus sp. & 0 & 16 & 8 & 12 & 4 & 8 & 0 & 4 & 56 & 0 & 16 & 4 \\
\hline Innocuonema sp. b & 20 & 4 & 20 & 8 & 12 & 20 & 8 & 8 & 8 & 32 & 32 & 36 \\
\hline Desmodora sp. & 16 & 8 & 12 & 4 & 4 & 24 & 4 & 28 & 24 & 0 & 16 & 12 \\
\hline Sabatieria sp. & 4 & 40 & 0 & 8 & 4 & 8 & 0 & 0 & 24 & 8 & 16 & 24 \\
\hline Metachromadora (M.) sp. c & 0 & 0 & 0 & 0 & 0 & 36 & 0 & 0 & 16 & 12 & 12 & 48 \\
\hline Chromaspirina sp. b & 0 & 16 & 0 & 8 & 0 & 16 & 36 & 56 & 16 & 16 & 16 & 64 \\
\hline Theristus sp. c & 8 & 28 & 0 & 8 & 0 & 4 & 36 & 36 & 16 & 32 & 20 & 8 \\
\hline Tricordorina sp. & 0 & 0 & 0 & 8 & 4 & 24 & 0 & 4 & 0 & 12 & 28 & 40 \\
\hline Oncholaimus sp. & 0 & 32 & 4 & 8 & 0 & 8 & 4 & 16 & 24 & 8 & 20 & 4 \\
\hline Innocuonema sp. d & 0 & 0 & 12 & 12 & 8 & 0 & 0 & 0 & 0 & 4 & 0 & 0 \\
\hline Metachromadora (M.) sp. d & 16 & 4 & 12 & 4 & 12 & 0 & 0 & 4 & 8 & 12 & 0 & 0 \\
\hline Total (all species) & 488 & 924 & 524 & 584 & 364 & 592 & 456 & 788 & 932 & 816 & 996 & 740 \\
\hline
\end{tabular}


Figs. 2 and 3 show the response of nematode abundances to natural ray disturbance ( 3 pit-and-control pairs) and short-term disturbance (2 pit-and-control pairs). Two-way analysis of variance at each sampling date detected significant differences between pit (clear) and background (hatched) areas on the first and third sampling dates of the experiment. On the second sampling date, the mean of the background samples was almost twice the mean of the pit samples, but the difference was not significant $(\mathrm{p}=0.65)$. By the fourth sampling date, the average densities of nematodes in the pits exceeded the background values.

The short-term artificial pits were tested in a less powerful 2-way ANOVA because only 2 pits were studied. Significant differences between pit and background samples were detected up to $5 \mathrm{~h}$ after their formation. Because the densities of nematodes in the natural pits at $0 \mathrm{~h}$ were approximately the same as densities at $5 \mathrm{~h}$ in the short-term pits, it was concluded that the natural pits were on the average about 5-h old when first sampled.

We collected 116 nematode species during the study. The 12 dominant species comprised $70 \%$ of the total fauna, and the addition of the next 8 most abundant species increased the cumulative total to $83 \%$ (Table 2). Voucher collections of these species were deposited in the British Museum of Natural History and at the Smithsonian Institution. We restricted the remaining analyses to these relatively abundant species.

If a nematode species were exploiting conditions resulting from the reduced nematode densities in ray pits, it should have become disproportionately abundant in pit as compared to background samples. To test

Table 4. Data used in the second set of Mantel-Haenszel tests. Only species-time combinations that were significant in the first half of the data are shown ( $\mathrm{P}=$ pit, $\mathrm{B}=$ background). For consistency of presentation, numbers obtained by using the subsampler were multiplied by 4

\begin{tabular}{|c|c|c|c|c|c|c|c|c|c|c|c|c|}
\hline \multirow[b]{2}{*}{ Species } & \multicolumn{6}{|c|}{ Hour 0} & \multicolumn{6}{|c|}{ Hour 24} \\
\hline & $P=1$ & $1 \mathrm{~B}$ & $P^{*}$ & 2 B & $\mathrm{p} \cdot 3$ & $3 \mathrm{~B}$ & $\mathrm{P}$ & 1 B & & ${ }^{2} \mathrm{~B}$ & $\mathrm{P}$ & $3 \mathrm{~B}$ \\
\hline Theristus sp. a & & & & & & & 80 & 196 & 56 & 208 & 52 & 164 \\
\hline $\begin{array}{l}\text { Metachromadora (Metachromadoroides) sp. a } \\
\text { Monoposthia sp. }\end{array}$ & 17 & 116 & 23 & 48 & 7 & 48 & 40 & 48 & 16 & 16 & 20 & 44 \\
\hline Theristus sp. b & 6 & 60 & 7 & 32 & 10 & 36 & & & & & & \\
\hline \multicolumn{13}{|l|}{$\begin{array}{l}\text { Chromadorella sp. } \\
\text { Innocuonema sp. a } \\
\text { Microlaimus sp. }\end{array}$} \\
\hline Innocuonema sp. b & 5 & 36 & 3 & 4 & 9 & 32 & & & & & & \\
\hline Innocuonema sp. c & 1 & 0 & 4 & 8 & 6 & 16 & & & & & & \\
\hline Oncholaimus sp. & 0 & 4 & 1 & 4 & 1 & 4 & & & & & & \\
\hline Innocuonema sp. d & 3 & 8 & 2 & 0 & 3 & 4 & & & & & & \\
\hline Metachromadora (M.) sp. d & 0 & 0 & 0 & 8 & 2 & 0 & & & & & & \\
\hline \multirow[t]{3}{*}{ Total (all species) } & 125 & 1012 & 158 & 604 & 156 & 712 & 392 & 672 & 704 & 844 & 356 & 836 \\
\hline & \multicolumn{6}{|c|}{ Hour 48} & \multicolumn{6}{|c|}{ Hour 96} \\
\hline & $\mathrm{P}^{1}$ & $1 \mathrm{~B}$ & $\mathrm{P}$ & 2 B & $\mathrm{P}^{3}$ & $3 \mathrm{~B}$ & $\mathrm{p}^{1}$ & $1 \mathrm{~B}$ & $P^{2}$ & 2 B & $\mathrm{P}^{3}$ & $3 \mathrm{~B}$ \\
\hline \multicolumn{13}{|l|}{ Theristus sp. a } \\
\hline Metachromadora (Metachromadoroides) sp. a & 44 & 28 & 24 & 56 & 16 & 32 & & & & & & \\
\hline Monoposthia sp. & 20 & 20 & 12 & 60 & 12 & 24 & & & & & & \\
\hline Theristus sp. b & 16 & 12 & 12 & 20 & 4 & 12 & & & & & & \\
\hline Chromadorella sp. & & & & & & & 196 & 16 & 8 & 4 & 16 & 8 \\
\hline Innocuonema sp. a & 8 & 16 & 28 & 48 & 0 & 28 & & & & & & \\
\hline Microlaimus sp. & & & & & & & 4 & 24 & 8 & 48 & 40 & 8 \\
\hline Innocuonema sp. b & & & & & & & 12 & 4 & 0 & 16 & 4 & 20 \\
\hline \multirow{2}{*}{\multicolumn{13}{|c|}{$\begin{array}{l}\text { Innocuonema sp. c } \\
\text { Oncholaimus sp. }\end{array}$}} \\
\hline & & & & & & & & & & & & \\
\hline $\begin{array}{l}\text { Innocuonema sp. d } \\
\text { Metachromadora (M.) sp. d }\end{array}$ & 8 & 4 & 4 & 24 & 0 & 0 & & & & & & \\
\hline Total (all species) & 488 & 640 & 467 & 556 & 292 & 404 & 656 & 704 & 944 & 832 & 872 & 648 \\
\hline
\end{tabular}


this hypothesis, we first randomly chose 1 of the 2 replicate cores from each pit at each sampling time to test each species for disproportionate abundance using the Mantel-Haenszel test and then repeated the procedure on the second half of the data. We used this technique to control the inflation of Type-I error (the probability of rejecting a true null hypothesis) caused by multiple testing by insisting that significant disproportionate abundance be detected in both halves of the data. The family-wide error rate can be estimated under these circumstances as the product of the significance level used in the first test and that used in the second, multiplied by the number of tests performed. In our case $0.05 \times 0.05 \times 20$ equals 0.05 . Despite the fact that we tested 20 species on each day, the probability of a rejection of a true null hypothesis remained 0.05 .

A total (over all times) of 17 tests showed significant disproportionate abundance of a species in the pit cores in the first half of the data (Table 3): Theristus sp. a., Innocuonema spp. b, c, d, Oncholaimus sp., and Metachromadora spp. a, d at Hour $0_{i}$ Theristus sp. a and Metachromadora sp. a, at Hour 24; Theristus sp. b, Innocuonema spp. a, b, d, Metachromadora sp. a and Monspothia sp. at Hour 48; and Microlaimus sp. and Chromadorella sp. at Hour 96. Only Chromadorella sp. at Hour 96 was significant when tested in the second half of the data (Table 4).

\section{DISCUSSION}

Sediment disturbance by rays was intense (an average of $0.91 \%$ of the area reworked $\mathrm{d}^{-1}$ ) and persistent (seasons lasting $\sim 270 \mathrm{~d}$ ), suggesting that only a relatively small proportion of the study site is free from disturbance for an entire year. The disturbance had a great effect on the nematodes, reducing densities by at least $80 \%$. For $3 \mathrm{~d}$ after disturbance, nematode densities in the pits were below background levels. These facts suggest that a nematode species might profitably exploit the disturbed patches. However, although a seemingly important disturbance is present in this community, only one nematode species becomes disproportionately abundant during the recovery. The response pattern of this species requires examination. Its dispersion was markedly pitchy in both pit and control samples over all times. The fact that at Hour 0 this species was as disproportionally abundant in control as it was at Hour 96 in the treatment (Table 3) suggests that it was not responding to ray-pit disturbance. In sum, the result expected under the Grassle and Sanders (1973) model was not obtained.

Disturbance does not appear to be structuring this community by permitting competitively subordinate species to numerically exploit conditions in a disturbed patch during the early portion of patch recovery. However, disturbance may be important to the organization of this community in ways our experiment could not detect, e.g. a species could gain a necessary advantage from disturbed patches without increasing its proportional abundance in them (Thistle, 1981). Also, disturbances may keep species' abundances generally below levels where competitive exclusion occurs (Dayton and Hessler, 1972) and thereby be fundamentally important to the persistence of competitively subordinate species.

Reidenauer and Thistle (1981) came to the same conclusion in their study of the harpacticoid copepods from these samples. In contrast, Thistle (1980) found that 2 harpacticoid species responded to a smaller disturbance in this habitat made by an acorn worm, and VanBlaricom $(1978,1982)$ reported that several macrofaunal species responded to subtidal ray-pit disturbance off California. The heterogeneity of these results suggests that the effect of disturbance is both site and species dependent.

An explanation of our findings that no nematode species responds to ray pits may come from an investigation of dispersal rates of nematode species. Nematode species may be unable to respond to disturbance because they lack sufficient dispersal capabilities to arrive consistently at newly opened space. This inability could explain why none of these nematode species has been able to develop a consistent numerical response associated with disturbance.

The rate of recolonization reported here, over $48 \mathrm{~h}$ to repopulate a $0.7 \mathrm{~m}^{2}$ area, is much slower than that in the intertidal region of South Carolina (12 h for a $9-\mathrm{m}^{2}$ man-made disturbance; Sherman and Coull, 1980). However, the results are consistent with current speeds measured at the 2 areas, $15.5 \mathrm{~cm} \mathrm{~s}^{-1}$ in South Carolina and $4.3 \mathrm{~cm} \mathrm{~s}^{-1}$ in the Gulf of Mexico. Also, bedload transport associated with the intertidal study appears to be much less important at our subtidal site. Reidenauer and Thistle (1981) found complete recolonization by harpacticoids after $24 \mathrm{~h}$, indicating that in this subtidal site there may be important differences in locomotion and current dispersal rates between nematodes and harpacticoids as suggested by Bell and Sheman (1980) for an intertidal soft bottom.

Acknowledgements. M. Butterworth, R. Dennis, C. Kocur, W. Lindberg, L. Parker, and W. Ravenel dove with us. C. McCulloch advised us on statistics. A. Thistle and $M$. Christian read and commented on the manuscript. We thank these people for their kind help. The research was supported, in part, by the Office of Naval Research contract No0014-75-C-0201 to D.T. 


\section{LITERATURE CITED}

Barnett, P. R. O. (1968). Distribution and ecology of harpacticoid copepods of an intertidal mudflat. Int. Revue ges. Hydrobiol. 53: 177-209

Bell, S. S., Sherman, K. M. (1980). A field investigation of meiofaunal dispersal: tidal resuspension and implications. Mar. Ecol. Prog. Ser. 3: 245-249

Cairns, J. Jr., Kaesler, R. L., Kuhn, D. L., Plafkin, J. L., Yongue, W. H. (1976). The influence of natural perturbation on protozoan communities inhabiting artificial substrates. Trans. Am. microsc. Soc. 95: 646-653

Clements, F. E. (1916). Plant succession: analysis of the development of vegetation. Carnegie Inst. Wash. Publ. 242: $1-512$

Connell, J. H. (1978). Diversity in tropical rain forests and coral reefs. Science, N. Y. 199: 1302-1310

Conover, W. J. (1971). Practical nonparametric statistics. Wiley \& Sons, New York

Dayton, P. K. (1971). Competition, disturbance and community organization: the provision and subsequent utilization of space in a rocky intertidal community. Ecol. Monogr. 41: $351-389$

Dayton, P. K. (1973). Dispersion, dispersal and persistence of the annual intertidal algae Postelsia palmaeformis Ruprecht. Ecology 54: 433-438

Dayton, P. K., Hessler, R. R. (1972). Role of biological disturbance in maintaining diversity in the deep sea. Deep Sea Res. 19: 199-208

Grassle, J. F., Sanders, H. L. (1973). Life histories and the role of disturbance. Deep Sea Res. 20: 643-659

Harper, J. L. (1977). Population biology of plants. Academic Press, London

Johnson, R. G. (1970). Variations in diversity within benthic marine communities. Am. Nat. 104: 285-300
Osman, R. W. (1977). The establishment and development of a marine epifaunal community. Ecol, Monogr. 47: 37-63

Paine, R. T (1979). Disaster, catastrophe, and local persistence of the sea palm Postelsia palmaeformis. Science, N. Y. 205: 685-687

Platt, W. J. (1975). The colonization and formation of equilibrium plant species associations on badger disturbances in a tall-grass prairie. Ecol. Monogr. 45: 285-305

Reidenauer, J. A., D. Thistle, D. (1981). Response of a softbottom harpacticoid copepod community to stingray (Dasyatis sabina) disturbance. Mar. Biol. 65: 261-267

Sherman, K. M., Coull, B. C. (1980). The response of meiofauna to sediment disturbance. J. exp. mar. Biol. Ecol 46: 59-71

Snedecor, G. W., Cochran, W. G. (1976). Statistical methods Iowa State University Press, Ames

Sokal, R. R., Rohlf, R. J. (1969). Biometry. W. H. Freeman, San Francisco

Sousa, W. P. (1979). Disturbance in marine intertidal boulder fields: the nonequilibrium maintenance of species diversity. Ecology 60: 1225-1239

Thistle, D. (1980). The response of a harpacticoid copepod community to a small-scale natural disturbance. J. mar. Res. 38: 381-395

Thistle, D. \{1981\}. Natural physical disturbance and communities of marine soft bottoms. Mar. Ecol. Prog. Ser. 6: 223-228

VanBlaricom, G. R. (1978). Disturbance, predation, and resource allocation in a high-energy sublittoral sand bottom ecosystem: experimental analyses of critical structuring processes for the infaunal community. Dissertation, University of California, San Diego

VanBlaricom, G. R. (1982). Experimental analyses of structural regulation in a marine sand community exposed to oceanic swell. Ecol. Monogr. 52: 283-305 